\title{
PERGESERAN SIKAP HAKIM PERADILAN AGAMA DI KOTA MEDAN DALAM PENETAPAN AHLI WARIS PENGGANTI SEBELUM DAN SESUDAH KHI
}

\author{
Abd. Mukhsin \\ Fakultas Syariah IAIN Sumatera Utara \\ Jl. Willem Iskandar Pasar V Medan Estate, 20371 \\ e-mail: abdmukhsin@gmail.com
}

\begin{abstract}
This study examines the relationship between the introduction of the Compilation of Islamic Law (KHI) in 1991 and the shift of the attitudes Islamic court judges taking inheritance as a case in point. Prior to the introduction of KHI the judges are urged to refer to the classical works of Islamic jurisprudents in giving their judgment, the consequence of which gives the impression that there is no legal certainty in the decision of Islamic courts. The author argues that in post-introduction of $\mathrm{KHI}$ there has been a shift in the attitude of judges in determining biological status of an heir who had died prior to the predecessor. The author concludes that the emergence of the compilation has significant impact in improving the position of the Islamic court judges administratively, and that they were responsive to maintaining social equalities.
\end{abstract}

Kata Kunci: KHI, sikap hakim, Peradilan Agama, ahli waris pengganti

\section{Pendahuluan}

Sebelum tahun 1991, tepatnya pra keluarnya Kompilasi Hukum Islam (KHI), sangat mungkin bagi hakim Pengadilan Agama untuk memberikan putusan yang berbeda-beda dalam menetapkan porsi (bagian) sebagian keluarga yang ditinggalkan oleh seseorang yang meninggal. Perbedaan bagian tersebut muncul karena terjadinya perbedaan pandangan para ahli hukum Islam terhadap status ahli waris dimaksud. Perbedaan pandangan itu terjadi karena adanya kebebasan bagi para hakim untuk mengambil pendapat kitabkitab fiqih klasik tertentu yang dalam istilah Hazairin disebut kitab 'Hukum Kewarisan Ahl al-Sunnah', sebagai dasar dalam pengambilan keputusan. Kitab fiqih klasik menetapkan bahwa orang yang lebih dahulu meninggal dunia dari orang yang akan dia warisi, tidak termasuk ahli waris bagi orang yang disebutkan belakangan. Contoh, seorang wanita yang lebih dahulu meninggal dunia dari kakaknya yang tidak memiliki anak, tidak termasuk 
ahli waris bagi si kakak, sehingga dengan demikian tidak ada dasar menempatkan anak seorang saudari perempuan yang lebih dahulu meninggal dunia dari kakaknya untuk mendapatkan bahagian ibunya yang lebih dahulu meninggal dari kakaknya. Hal ini semata-mata karena orang yang pertama lebih dahulu meninggal dunia.

Selanjutnya, sesuai fiqih Islam klasik seorang anak yang lebih dahulu meninggal dunia dan telah memiliki keturunan, tidak termasuk ahli waris bagi ayahnya yang meninggal. Dengan demikian, cucu seorang pewaris dari anaknya yang meninggal duluan darinya tidak termasuk ahli waris baginya karena terputusnya hubungan antara si kakek dengan cucunya. Konsekuensinya, cucu tidak akan memperoleh apapun dari warisan yang ditinggalkan, kecuali jika si kakek ada meninggalkan wasiat untuk memberikan atau menghibahkan sebahagian hartanya kepada cucu dimaksud.

Namun, sebagian besar ahli hukum Islam (Syafîiyah, Hanafiyah, Malikiyah dan Hanabilah) menyatakan bahwa ayat wasiat pada Q.S. al-Baqarah/2:180 telah dinasakh ketika ayat al-Qur'an yang mengatur tentang kewarisan diturunkan. Karenanya, menurut mereka, kata 'kutiba' yang ada dalam ayat tersebut tidak dapat diartikan dengan makna wajib. Dengan demikian, ketentuan hukum berwasiat itu tidaklah wajib, dengan kata lain tidak ada wasiat wajibah, bahkan berwasiat terhadap ahli waris tidak dibenarkan kecuali bagi mereka yang dinyatakan tidak memperoleh warisan, itupun sifatnya harus atas dasar kerelaan. ${ }^{1}$

Berbeda dengan prinsip yang ada di dalam kitab fiqih klasik di atas, Ibn Hazm memiliki pandangan bahwa ayat wasiat terdahulu menentukan suatu kewajiban hukum yang definitif bagi orang Islam untuk membuat wasiat yang akan didistribusikan kepada kerabat dekat yang bukan menjadi ahli waris. Lebih jauh lagi, ia berpendapat bahwa jika orang yang meninggal gagal memenuhi kewajiban tersebut ketika ia masih hidup, maka pengadilan harus membuat wasiat atas namanya. ${ }^{2}$ Logika hukum dari pendapat ini menyatakan, ketika orang yang sudah meninggal tidak menuliskan wasiat untuk para kerabat dekat yang tidak termasuk ahli waris, maka pengadilan harus bertindak seolaholah wasiat itu telah dibuat oleh orang yang meninggal tersebut. Walau kemudian ada masalah dalam penentuan kerabat dekat sebagai orang yang akan menerima wasiat wajibah, namun spesifikasi kerabat dekat tersebut mencakup kepada cucu yang orang tuanya telah meninggal terlebih dahulu (cucu yatim).

Selanjutnya, penspesifikasian kerabat dekat seperti diuraikan di atas kepada cucu yang orang tuanya telah meninggal terlebih dahulu, diuraikan secara rinci di dalam Hukum Barat (BW). Dalam Hukum Barat, kasus cucu yatim yang berfungsi menggantikan tempat orang tuanya yang telah meninggal terlebih dahulu disebut plaatsvervulling. Plaatsvervulling

${ }^{1}$ Wahbah al-Zuhailî, al-Fiqh al-Islâm wa Adillatuh, juz VIII, cet. 3 (Damsyik: Dâr al-Fikr, 1989), h. 122.

2 'Alî ibn Ahmad ibn ㅂazm, al-Muhallâ (Kairo: Idârah al-Tiba'ah al-Muniriyah, 1347 H.), h. 312 . 
atau pergantian tempat diatur di dalam pasal 841 sampai pasal 848, pasal 852, pasal 854 sampai pasal 857, pasal 860 dan pasal 866 BW. ${ }^{3}$ Dari pasal-pasal ini jelas menunjukkan bahwa BW telah mengatur secara rinci tentang penggantian tempat.

Sejalan dengan semakin berkurangnya bentuk keluarga besar (extended family) dan munculnya bentuk keluarga inti (nuclear family) di negara-negara Islam, tanggung jawab dari orang tua yang mati terhadap para keturunannya tidak akan terpenuhi hanya dengan membagikan warisan kepada keturunannya tingkat pertama (anak-anak) saja, karena garis lain dari keturunan orang yang mati, yang datang dari anak-anaknya, secara otomatis membentuk keluarga yang terpisah, juga harus dimasukkan dalam tanggung jawabnya. Dengan kata lain, kewajiban dari orang yang mati tidak akan terpenuhi dengan sempurna, jika hak-hak warisan dari satu garis keluarga secara total dihapuskan, tanpa dihubungkan langsung dengan garis keluarga yang lain di mana hubungan dengan leluhurnya masih ada. ${ }^{4}$

Adanya kebebasan bagi para hakim untuk mengambil pendapat tertentu dari sejumlah pendapat yang beraneka ragam memberi peluang yang lebih besar bagi lahirnya suatu keputusan yang berbeda untuk kasus yang sama seperti dalam hal penetapan ahli waris pengganti, sehingga kemudian terkesan bahwa tidak ada kepastian hukum dalam putusan Peradilan Agama (PA). Pandangan ini menjadi salah satu dasar bagi lahirnya Kompilasi Hukum Islam, yang ditetapkan berdasarkan INPRES Nomor 1/1991 tanggal 10 Juli 1991 dan Surat Keputusan pelaksanaannya dikeluarkan oleh Menteri Agama Nomor 154/1991 tanggal 22 Juli 1991 untuk merespons kebutuhan pada adanya unifikasi dasar hukum dan pandangan para hakim.

Permasalahan seperti di atas dapat dikatakan diadopsi dari hukum Barat kendatipun jauh sebelum lahirnya hukum Barat perbincangan ini telah disinggung oleh ahli hukum Islam termasuk Ibn Hazm, hanya saja beliau menggunakan terma yang lain dari yang ada di dalam BW untuk merujuk pada ahli waris sedemikian dan memberikan kepada mereka porsi (bagian) tertentu yang berbeda dengan yang tertuang di dalam hukum Barat.

Permasalahan ahli waris pengganti ini tercantum di dalam Kompilasi Hukum Islam (KHI) pasal 185 sebagai berikut:

(1) Ahli waris yang meninggal lebih dahulu dari pada si pewaris maka kedudukannya dapat digantikan oleh anaknya, kecuali mereka yang tersebut dalam pasal $173 .^{5}$

${ }^{3}$ Syahrizal, Hukum Adat dan Hukum Islam di Indonesia: Refleksi Terhadap Beberapa Bentuk Integrasi Hukum dalam Bidang Kewarisan di Aceh (Yogyakarta: Nadiya Foundation, 2004), h. 290-292.

${ }^{4}$ N.J. Coulson, Succession in the Muslim Family (Cambridge: The University Press, 1971), h. 144.

${ }^{5}$ Pasal tersebut menjelaskan bahwa seorang terhalang menjadi ahli waris apabila dengan putusan hakim yang telah mempunyai kekuatan hukum yang tetap, dihukum karena: a) dipersalahkan telah membunuh atau mencoba membunuh atau menganiaya berat pada pewaris, b) dipersalah- 
(2) Bagian bagi ahli waris pengganti tidak boleh melebihi dari bagian ahli waris yang sederajat dengan yang diganti. ${ }^{6}$

Ayat (1) dari pasal di atas menjelaskan bahwa kedudukan ahli waris yang meninggal lebih dahulu dari si pewaris dapat digantikan oleh anaknya. Ini berarti jika seorang anak yang telah memiliki keturunan lebih dahulu meninggal dari ayahnya, maka posisi si anak dapat diisi oleh keturunannya (cucu pewaris). Isi ayat ini menganut sistem kewarisan bilateral, ${ }^{7}$ yaitu suatu sistem kewarisan yang menciptakan persamaan hak dan kedudukan antara pihak laki-laki dan perempuan dalam mewarisi harta. Dengan kata lain, baik anak laki-laki maupun anak perempuan, begitu juga cucu dari anak laki-laki maupun cucu dari anak perempuan sama-sama dinyatakan sebagai ahli waris.

Sedangkan ayat (2) menetapkan bahwa ahli waris pengganti akan mengambil seluruh bahagian yang seyogianya menjadi bahagian orang yang diganti, apabila orang yang diganti itu masih hidup pada saat pewaris meninggal dunia, dengan ketentuan bahwa bahagian tersebut tidak boleh lebih besar dari perolehan ahli waris yang masih hidup yang sederajat dengan orang yang diganti. Dengan kata lain, jika anak pewaris yang telah meninggal mewarisi dengan seorang anak laki-laki dan seorang anak perempuan pewaris, maka ahli waris pengganti hanya akan memperoleh porsi yang setara dengan bahagian anak perempuan pewaris berapapun jumlah ahli waris pengganti tersebut.

Berdasarkan penjelasan terdahulu, maka dianggap perlu untuk membahas keputusan hakim Peradilan Agama yang ada di kota Medan mengenai ahli waris pengganti, baik keputusan hakim di tingkat Pengadilan Agama maupun keputusan hakim di tingkat Pengadilan Tinggi Agama pada masa sebelum dan sesudah keluarnya Kompilasi Hukum Islam tahun 1991 untuk mengetahui tingkat pergeseran sikap hakim dalam memutus kasus ahli waris pengganti.

Konsep dasar terkait dengan pokok masalah dalam penelitian ini adalah bahwa kaedah-kaedah hukum kewarisan menurut fiqih klasik, pasal $185 \mathrm{KHI}$ dan perubahan sosial akan mempengaruhi sikap hakim dalam memberikan suatu keputusan. Teoritical Frameworknya adalah sejauh mana konsistensi konsep ini dengan kenyataan yang terdapat di dalam keputusan hakim.

Penelitian ini bertujuan untuk: 1) mengetahui bagaimana pendapat hakim Peradilan Agama di tingkat Pengadilan Agama dan Pengadilan Tinggi Agama mengenai ahli waris dan anak dari ahli waris yang lebih dahulu meninggal dunia dari si pewaris pada

kan secara memfitnah telah mengajukan pengaduan bahwa pewaris telah melakukan suatu kejahatan yang diancam dengan hukuman 5 tahun penjara atau hukuman yang lebih berat. Lihat Tim Redaksi Fokusmedia, Kompilasi Hukum Islam (Bandung: Fokusmedia, 2005), h. 57.

${ }^{6}$ Departemen Agama RI, Kompilasi Hukum Islam di Indonesia (Jakarta: Departemen Agama RI, Ditbinperta, 1997/1988), h. 82.

${ }^{7}$ Amir Syarifuddin, Hukum Kewarisan Islam (Jakarta: Prenada Media, 2004), h. 19. 
masa sebelum keluarnya KHI tahun 1991 (time 1) dan pada masa sesudah KHI (time 2). 2) melihat pergeseran dan perubahan sikap hakim dalam memilih dasar hukum yang menjadi acuan dalam memutuskan status ahli waris yang lebih dahulu meninggal dunia dari pewarisnya, dan sekaligus menetapkan penggantinya.

Perbedaan sikap hakim ketika memilih salah satu dari beberapa dasar hukum yang dapat dijadikan acuan dalam pengambilan keputusan telah banyak dikaji oleh para ahli maupun peneliti dan pemerhati pada umumnya. Diantaranya adalah penelitian yang dilakukan oleh M. Atho Mudzhar dan Edi Riyadi ${ }^{8}$ yang mencoba melihat perubahan sikap dan perilaku hakim Pengadilan Agama DKI Jakarta terhadap penerapan asas kesaksian perempuan sekaligus menjaring alasan mereka dalam melakukan perubahan perilaku tersebut. Di awal tulisannya, M. Atho Mudzhar dan Edi Riyadi mengemukakan latar belakang yang menjadi penyebab terjadinya perubahan pola perilaku hakim. Perlu diketahui bahwa di awal dekade delapan puluhan, lembaga Peradilan Agama mulai intensif bersentuhan dengan lembaga Peradilan Tertinggi yaitu Mahkamah Agung RI. Sebelumnya, Pengadilan Agama nyaris tidak melakukan interaksi dengan Mahkamah Agung walaupun dalam pasal 11 Undang-Undang Nomor 14 Tahun 1970 dinyatakan bahwa pembinaan Pengadilan Agama di bidang justisial di bawah kewenangan Mahkamah Agung (sejak tanggal 15 Januari 2004 Undang-Undang Nomor 14 Tahun 1970 telah diganti dengan Undang-Undang Nomor 5 Tahun 2004. Dengan undang-undang ini semua kewenangan pembinaan Pengadilan Agama berada di bawah Mahkamah Agung).

Sebelum dekade awal delapan puluhan, dalam putusan Pengadilan Agama banyak dicantumkan kaidah-kaidah hukum fiqih sebagai dasar konsideran hukum para hakim, akan tetapi setelah Pengadilan Agama bersinergi dengan Mahkamah Agung, mulai jarang ditemukan kaidah-kaidah hukum fiqih yang dijadikan konsideran putusan.

Dalam penelitian ini M. Atho Mudzhar dan Edi Riyadi menemukan bahwa sebelum tahun 1980, perilaku hakim Pengadilan Agama di DKI Jakarta dalam menolak kesaksian perempuan terlihat sangat kuat. Seluruh perkara cerai dan itsbat nikah yang berjumlah 30 berkas perkara yang diputus sebelum tahun 1980, diputus tanpa menggunakan saksi perempuan (hanya saksi laki-laki). Demikian juga dalam perkara waris, hampir seluruhnya diputus dengan saksi laki-laki, hanya satu perkara yang diputus menggunakan 5 orang saksi laki-laki dan dua orang saksi perempuan sebagai tambahan.

Apabila perilaku hakim di Pengadilan Agama DKI Jakarta pada masa sebelum tahun 1980 dibandingkan dengan perilaku hakim di pengadilan yang sama pada tahun 2005, keadaannya telah berubah atau bergeser begitu jauh. Para hakim cenderung menerima kesaksian perempuan, bahkan memperlakukan kesaksian mereka sama dengan kesaksian laki-laki.

${ }^{8}$ M. Atho Mudzhar dan Edi Riyadi, "Perilaku Hakim Terhadap Pelaksanaan Kesaksian Perempuan di Pengadilan Agama DKI Jakarta”, dalam An Nisa'a: Jurnal Kajian Gender dan Masyarakat, Vol. 1, Nomor 1 (Juni, 2005), h. 43-58. 
Penelitian dan kajian yang lain adalah penelitian ${ }^{9}$ yang dilakukan oleh $\mathrm{H}$. Satria Effendi M. Zein. Beliau meneliti berkas perkara Pengadilan Agama Mataram yang diputus oleh pengadilan di penghujung masa kebebasan memilih argumen dari sejumlah argumen hukum yang tersedia atau di masa awal pemberlakuan KHI. Perkara tersebut diajukan ke pengadilan oleh H. Nursaid, H. Muslim, H. Ma'rif dan Mas'ud (cucu-cucu Amaq Itrawan yang meninggal pada tahun 1930) sebagai penggugat terhadap Le Putrahimah, anak perempuan dari Amaq Nawiyah (saudara laki-laki Amaq Itrawan) yang lebih dulu meninggal darinya. Amaq Nawiyah meninggal dunia sebelum tahun 1930 dengan meninggalkan seorang anak perempuan yang bernama Le Putrahimah dan harta warisan berupa tanah kebun seluas 6 (enam) hektar, yang ketika pewaris meninggal belum dibagi wariskan, melainkan langsung dikuasai dan dikelola oleh Amaq Itrawan karena Le Putrahimah masih kecil dan setelah Amaq Itrawan meninggal, harta tersebut dikuasai istri dan anak-anak Amaq Itrawan. Le Putrahimah dapat menguasai harta warisan tersebut setelah istri dan anak-anak Amaq Itrawan meninggal. Belakangan cucu-cucu Amaq Itrawan seperti disebutkan di awal, menggugat Le Putrahimah karena mereka merasa berhak atas sebagian harta warisan tersebut.

Pengadilan Agama Mataram memutus perkara, namun para pihak yang berperkara merasa tidak puas dengan putusan tersebut, lalu mereka mengajukan banding ke Pengadilan Tinggi Agama (PTA) Mataram dan selanjutnya mengajukan kasasi ke Mahkamah Agung. Yang menarik untuk dicermati dalam putusan perkara ini adalah bahwa menurut Pengadilan Tinggi Agama Mataram harta peninggalan Amaq Nawiyah berupa tanah perkebunan itu harus dibagi antara ahli waris yang terdiri dari seorang anak perempuan (Le Putrahimah) dan saudara laki-laki dari si pewaris (Amaq Itrawan). Menimbang bahwa dari hasil pemeriksaan dalam sidang Pengadilan Agama Mataram telah terbukti bahwa tanah-tanah kebun sengketa tersebut belum dibagi kepada ahli waris yang berhak menerimanya, yaitu Le Putrahimah (anak perempuan) dan Amaq Itrawan (saudara laki-laki), dan karenanya tanah-tanah kebun sengketa masih merupakan tanah syarikat antara para ahli waris. Dalam pertimbangan hukumnya terdapat satu pendapat yang mengatakan bahwa saudara laki-laki dari pewaris, yaitu Amaq Itrawan, mendapat pembagian harta warisan bersama-sama dengan anak perempuan si pewaris, yaitu Le Putrahimah. Dengan demikian saudara laki-laki dari si pewaris tidak terhijab atau tidak terdinding oleh anak perempuan si pewaris. Sedangkan hakim Mahkamah Agung, ketika membatalkan putusan Pengadilan Tinggi Agama Mataram, dalam salah satu pertimbangan hukumnya menjelaskan bahwa selama masih ada anak, baik laki-laki maupun perempuan, maka hak waris orang-orang yang mempunyai hubungan darah dengan pewaris kecuali orangtua, suami dan istri, menjadi terhijab. Pendapat ini sejalan dengan pendapat Ibn 'Abbâs (salah seorang ahli tafsir masa sahabat) yang menafsirkan kata walad pada Q.S.

\footnotetext{
${ }^{9}$ Satria Effendi M. Zein, Problematika Hukum Keluarga Islam Kontemporer: Analisis Yurisprudensi dengan Pendekatan Ushuliyah (Jakarta: Kencana, 2004), h. 293-306.
} 
al-Nisầ/4: 176 dengan anak laki-laki dan anak perempuan. Dengan demikian Amaq Itrawan, paman dari Le Putrahimah, dan cucu-cucunya yaitu H. Nursaid dan yang lainnya, menjadi tertutup atau terhijab untuk mendapat warisan. Dari perkara ini terlihat secara jelas perbedaan putusan yang diberikan oleh hakim Pengadilan Tinggi Agama Mataram dengan putusan yang diberikan oleh hakim Mahkamah Agung. Pengadilan Tinggi Agama Mataram dalam keputusannya berpegang pada penafsiran mayoritas ulama terhadap kata walad yang ada pada Q.S. al-Nisâ'/4: 176 yang hanya merujuk pada anak laki-laki, dalam arti tidak mencakup anak perempuan, sedangkan Mahkamah Agung berpegang pada penafsiran Ibn 'Abbâs yang menafsirkan walad dengan anak laki-laki maupun anak perempuan.

Selanjutnya Pagar dalam laporan penelitiannya menemukan bahwa Mahkamah Agung dalam beberapa keputusannya, diantaranya yang tertuang dalam salinan Keputusan Mahkamah Agung Republik Indonesia Nomor 04 K/AG/1993 telah memberlakukan konsep ahli waris pengganti dalam setiap keputusan yang dikeluarkannya. Dalam arti Mahkamah Agung telah menghitung cucu pewaris dari anaknya yang lebih dulu meninggal dunia daripadanya sebagai ahli waris untuk menggantikan kedudukan orangtua mereka dan menentukan bagian masing-masing, dengan perbandingan $2: 1$ antara bagian anak laki-laki dengan anak perempuan. Putusan Mahkamah Agung ini cenderung sejalan dengan putusan Pengadilan Agama asal perkara (Pengadilan Agama Lubuk Linggau), namun membatalkan putusan Pengadilan Tinggi Agama. Dengan demikian mereka (cucu yang orangtuanya lebih dulu meninggal dari pewaris) yang semula dalam fiqih Sunni atau klasik tidak memperoleh harta warisan karena terhijab oleh anak lakilaki, ternyata melalui ketentuan yang diatur dalam pasal $185 \mathrm{KHI}$ dinyatakan memperoleh harta warisan. Walaupun Mahkamah Agung tidak menyatakan dengan tegas bahwa dia telah menerapkan ketentuan ahli waris pengganti dengan berpedoman pada pasal $185 \mathrm{KHI}$, tetapi dengan mengamati keputusannya dipahami bahwa MA telah berpendirian demikian. ${ }^{10}$

\section{Metode}

Penelitian ini adalah penelitian historis, sosiologis dan deskriptif. Sesuai judul di atas, maka lokasi penelitian ini adalah Pengadilan Agama dan Pengadilan Tinggi Agama Medan. Dua tempat ini dipilih atas pertimbangan bahwa disamping waktu penyelesaian dan dana penelitian sangat terbatas, lokasi ini akan lebih mudah dijangkau, karena berada di dalam kota.

${ }^{10}$ Pagar, "Sisi Keadilan Ahli Waris Pengganti Dalam Pembaharuan Hukum Islam Indonesia: Suatu Kajian Terhadap Kompilasi Hukum Islam Indonesia", Disertasi pada Program Doktor IAIN Syarif Hidayatullah (Jakarta: IAIN Syarif Hidayatullah, 2001), h. 176. 
Sumber data diperoleh dari Shari'a Court Records ${ }^{11}$ atau dokumentasi keputusankeputusan hakim Pengadilan Agama dan Pengadilan Tinggi Agama Medan. Analisis data dilakukan dengan menggunakan metode induktif ${ }^{12}$ komparatif, dan selanjutnya membandingkan keadaan sebelum tahun 1991 dengan keadaan sesudahnya yang digambarkan oleh putusan hakim Pengadilan Agama yang ada di kota Medan dalam 7 (tujuh) berkas perkara. Tahun 1991 diambil karena pada waktu tersebut adalah awal dari pemberlakuan Kompilasi Hukum Islam di Indonesia.

Berkas putusan Pengadilan Agama yang dapat diperoleh dan kemudian dipelajari adalah dari tahun 1977 sampai dengan tahun 2005. Rentang waktu tersebut dibagi kepada 2 (dua) periode besar. Periode pertama adalah sebelum keluarnya KHI pada tahun 1991. Periode ini diklasifikasikan kepada dua masa, yaitu dari tahun 1977 sampai dengan 1984 dan dari tahun 1985 sampai dengan pertengahan tahun 1991. Periode kedua adalah setelah berlakunya secara efektif KHI, yakni mulai akhir Juli 1991 sampai dengan tahun 2005.

\section{Hasil dan Pembahasan}

\section{Hasil}

Setelah menelusuri sejumlah produk putusan hakim dalam menyelesaikan perkara waris mal waris untuk melihat putusan tentang penetapan ahli waris sesuai objek yang diteliti, hanya ditemukan 2 (dua) putusan untuk periode pertama tahun 1977 sampai dengan tahun 1984 sebagai berikut:

1. Putusan PTA Medan Nomor 04/1977 yang diputus pada tanggal 4 Mei 1977, asal perkara Pengadilan Agama Pematang Siantar Nomor 339/1976 tanggal 26 Nopember 1976.

2. Putusan PTA Medan Nomor 04/1979 yang diputus pada tanggal 31 Januari 1979, asal perkara Pengadilan Agama Gunung Sitoli No. 9/1978 tanggal 1 Agustus 1978.

Sedangkan untuk periode pertama tahun 1985 sampai dengan pertengahan 1991 hanya ada 1 (satu) putusan yang dianggap relevan, yaitu Putusan PTA Medan Nomor 05/ PTS/1991/1992 tanggal 29 Juni 1992, asal perkara Pengadilan Agama Tebing Tinggi Nomor 139/PTS/1990/PA TTD, tanggal 26 Nopember 1990.

Sedangkan untuk periode kedua, dari sejumlah produk putusan yang ada hanya 4 (empat) buah putusan yang dianggap relevan, yaitu:

${ }^{11}$ R. Stephen Humphreys, Islamic History: A Framework for Inquiry (USA: Bibliotheca Islamica, Minneapolis, 1988), h. 200.

${ }^{12}$ Melalui cara berpikir induktif seseorang berangkat dari fakta-fakta yang khusus, peristiwaperistiwa yang konkrit kemudian dari fakta-fakta atau peristiwa-peristiwa yang konkrit itu ditarik generalisasi yang bersifat umum. Earl Babbie, The Practice of Social Research (Belmot, California: Wadsworth Publishing Company, 1989), h. 39, bandingkan dengan Sutrisno Hadi, Metodologi Research, Jilid I (Yogyakarta: Yayasan Penerbitan Fakultas Psikologi UGM, 1981), h. 36. 
MIQOT Vol. XXXV No. 1 Januari-Juni 2011

1. Putusan PTA Medan Nomor 81/Pdt.G./1998/PTA Medan yang diputuskan pada tanggal 11 Februari 1999.

2. Putusan PTA Medan Nomor 367/Pdt.G./1998/PTA-Medan yang diputuskan pada tanggal 24 Februari 1999, asal perkara Pengadilan Agama Medan.

3. Penetapan Pengadilan Agama Medan Nomor 36/Pdt.P./2005/PA. Medan pada tanggal 24 Agustus 2005.

4. Penetapan Pengadilan Agama Medan Nomor 47/Pdt.P./2005/PA. Medan pada tanggal 18 Oktober 2005.

Rincian dari Shari'a Court Records atau dokumentasi keputusan-keputusan Peradilan Agama untuk periode pertama tahun 1977 sampai dengan tahun 1984 adalah sebagai berikut:

1. Keputusan PTA Medan Nomor 04/1977 yang diputus pada tanggal 4 Mei 1977 yang duduk perkaranya adalah:

Almarhum Supardi yang meninggal pada tanggal 11 April 1970 meninggalkan: Semi (istri), Paerah (anak perempuan almarhum),Paeran (anak laki-laki yang meninggal lebih dahulu dari almarhum Supardi) dan sewaktu meninggal dunia meninggalkan seorang istri bernama Sayam, tiga orang anak laki-laki masing-masing bernama Ibrahim, Bahrum dan Razali dan empat orang anak perempuan, masing-masing bernama Suparmi, Ratna, Fatma dan Salmah.

Dalam kasus di atas, Semi (istri almarhum Supardi) adalah Tergugat/Pembanding, sedangkan Paerah (anak perempuan almarhum) adalah Penggugat/Terbanding. Semi dalam hal ini melakukan banding karena Pengadilan Agama/Mahkamah Syar'iyah Pematang Siantar dengan penetapannya tanggal 26 Nopember 1976 No. 339/1976 telah memutuskan bahwa Semi, Paerah, Suparmi, Ibrahim, Ratna, Bahrum, Fatma, Razali dan Salmah adalah ahli waris dan mewarisi seluruh harta peninggalan almarhum Supardi. Disamping itu, PA Pematang Siantar juga menetapkan bahwa bagian Semi adalah $1 / 8$ dari harta peninggalan Supardi. Harta peninggalan Supardi yang dimaksudkan adalah 2/3 dari harta pencaharian bersama dan setelah dikeluarkan darinya wasiat-wasiat dan hutang. Semi melakukan upaya banding untuk memperoleh $1 / 2$ bagian dari harta pencaharian bersama.

Hakim PTA Medan yang terdiri dari M. Saleh Rasyid, SM. HK. (Ketua), K.H. Ahmad Nasution (anggota), Arifin Isa (anggota) dan Drs. Zakwan Daiman (Panitera) di dalam keputusannya Nomor 04/1977 menguatkan putusan PA Pematang Siantar Nomor 339/ 1976 tanggal 26 Nopember 1976 yang menetapkan bahwa Sayam sebagai isteri Paeran yang meninggal dunia lebih dahulu dari Supardi tidak dipandang sebagai ahli waris atas harta peninggalan almarhum Supardi dan cucu almarhum Supardi dari anaknya Paeran ditetapkan sebagai ashabah. Berarti 3 (tiga) orang cucu laki-laki dan 4 (empat) orang cucu perempuan memperoleh sisa harta setelah dikeluarkan 1/8 untuk Semi dan $1 / 2$ untuk Paerah. Dalil yang dikemukakan bersumber dari kitab Rahbiyah tentang status seorang cucu perempuan atau lebih yang menjadi ashabah bila secara bersamaan 
mewarisi dengan cucu laki-laki disamping dasar hukum dari ayat al-Qur'an yang menjelaskan bagian laki-laki terdiri dari dua kali bagian perempuan.

2. Keputusan PTA Medan Nomor 04/1979 yang diputuskan pada tanggal 31 Januari 1979 yang duduk perkaranya adalah sebagai berikut:

Almarhumah Siti Nalaboh meninggal dunia pada tahun 1926 yaitu isteri dari almarhum Yahya yang telah meninggal dunia pada tahun 1925. Ketika Siti Nalaboh meninggal dunia, ahli warisnya adalah: Ahmad, anak laki-laki yang meninggal pada tahun 1943, Zubaenah, anak perempuan yang meninggal tahun 1964. Adapun anaknya yang lain, yaitu Ruhima (anak perempuan yang meninggal tahun 1922) dan meninggalkan anak Saniyah dan Abd. Rahman, dan Sutan Rahman (anak laki-laki yang meninggal tahun 1921) telah tidak mendapat pusaka lagi, karena lebih dahulu meninggal dunia dari Siti Nabaloh dan Yahya walaupun almarhumah Ruhima meninggalkan anak.

Gugatan ini diajukan ke PTA Medan oleh Husin bin Ahmad sebagai Tergugat/ Pembanding melawan Fatimah Siyah Caniago (anak-anak Zubainah) sebagai Penggugat/ Terbanding.

PTA Medan dengan hakim H. Abd. Madjid Siradj, MA (Ketua Majlis), K.H. Ahmad Nasution, M. Saleh Rasyid, SH dan Arifin Isa, masing-masing sebagai hakim anggota dan Drs. Zakwan Daiman sebagai Panitera, setelah memeriksa perkara tersebut akhirnya membatalkan penetapan Pengadilan Agama/Mahkamah Syar'iyah Gunung Sitoli Nomor 9/1978 tanggal 1 Agustus 1978. Alasan pembatalan pada pokoknya karena majlis hakim yang memeriksa perkara ini dianggap mengerjakan tugas di luar wewenangnya, sebab majlis tidak saja nenetapkan ahli waris tetapi juga membagikan pusaka kepada ahli waris. Langkah yang disebut belakangan dianggap oleh PTA melanggar wewenang Peradilan Agama.

Putusan untuk periode pertama mulai tahun 1985 sampai dengan pertengahan tahun 1991 adalah Putusan PTA Medan Nomor 05/PTS/1991/1992/PTA Medan, tanggal 29 Juni 1992. Asal perkara dari PA Tebing Tinggi Nomor 139/PTS/1990/PA TTD, tanggal 26 Nopember 1990.

Kasusnya adalah gugatan waris antara Mhd. Nursyah bin Kudin sebagai Tergugat/ Pembanding melawan Azhari bin Muhammad Haris sebagai Penggugat/Terbanding. Duduk perkaranya adalah bahwa almarhum Kudin telah meninggal dunia pada tahun 1967. Almarhum meninggalkan: Halimah (isteri), meninggal dunia pada tahun 1968. Mhd. Nur (anak kandung laki-laki), meninggal dunia pada tahun 1973. Mhd. Haris (anak kandung laki-laki), meninggal dunia pada tahun 1986. Mhd. Nursyah (anak kandung laki-laki).

Lalu, Azhari bin Muhammad Haris mengajukan gugatan ke PA Tebing Tinggi. Isi gugatannya memohon majlis untuk menetapkan ahli waris yang sah dari almarhum Kudin dan membagikan harta terperkara kepada ahli waris almarhum. Gugatan Azhari bin Muhammad 
Haris diterima oleh majlis hakim PA Tebing Tinggi dan sekaligus menetapkan dan menentukan pembagian tirkah sebagai berikut: Halimah (isteri), meninggal dunia pada tahun 1968, mendapat $1 / 8$ bagian atau $3 / 24$ bagian $=3$ bagian. Mhd. Nur (anak kandung laki-laki), meninggal dunia pada tahun 1973, ashabah bi al-nafsi, mendapat 7/24 bagian $=7$ bagian . Mhd. Haris (anak kandung laki-laki), meninggal dunia pada tahun 1986, asobah bi alnafsi, mendapat $7 / 24$ bagian $=7$ bagian. Mhd. Nursyah (anak kandung laki-laki), asobah bi al-nafsi, mendapat $7 / 24$ bagian $=7$ bagian .

Namun, PTA Medan dengan Majlis Hakim yang terdiri dari Drs. H. Zainal Arifin Syam (Ketua Majlis), Drs. Soufyan M. Saleh, SH dan Drs. Mahyiddin Usman, masing-masing sebagai hakim anggota, dibantu oleh Drs. Abd. Halim Ibrahim sebagai Panitera Pengganti, setelah melakukan pemeriksaan secara cermat, membatalkan Putusan PA Tebing Tinggi tanggal 26 Nopember 1990 Nomor 139/PTS/1990/PA-TTD dan menyatakan bahwa gugatan Penggugat/Terbanding tidak dapat diterima karena ternyata almarhum Kudin, selain meninggalkan ahli waris sebagaimana tersebut di atas, masih meninggalkan 2 (dua) orang cucu, masing-masing bernama: Lukman (laki-laki), dan Masnun (perempuan).

Keduanya adalah anak dari almarhum M. Saib bin Kudin yang telah lebih dahulu meninggal dari almarhum Kudin, yakni tahun 1947. Majlis dalam keputusannya untuk membatalkan keputusan PA Tebing Tinggi menyatakan bahwa kedua orang anak almarhum M. Saib bin Kudin sesuai ketentuan Hukum Islam berkedudukan sebagai ahli waris pengganti. Jadi, majlis berpendapat bahwa gugatan Penggugat/Terbanding tidak memenuhi persyaratan formil gugatan.

Rincian produk putusan untuk periode kedua adalah sebagai berikut:

1. Putusan PTA Medan Nomor 81/Pdt.G./1998/PTA-Medan yang diputuskan pada tanggal 11 Februari 1999.

Pangadilan Tinggi Agama Medan dalam hal ini mengadili perkara waris mal waris dalam perkara antara Samikun bin Martonadi sebagai pembanding melawan Ngadiem alias Tumbu sebagai terbanding. Duduk perkaranya adalah bahwa PA Lubuk Pakam tanggal 8 Oktober 1998 melalui putusan Nomor 089/Pdt.G./1998/PA-LPK menetapkan ahli waris yang mustahiq dari almarhum Katimun bin Martonadi yang meninggal dunia pada tanggal 14 Desember 1994 adalah: Isteri satu orang bernama Ngadiem alias Tumbu. Saudara kandung 3 (tiga) orang, yakni Samikun bin Martonadi (laki-laki), Samingun bin Martonadi (laki-laki), dan Mirah binti Martonadi (perempuan). 1 (satu) orang ahli waris pengganti, yakni Kaeran sebagai waris pengganti dari almarhumah Saminem binti Martonadi.

Samikun bin Martonadi sepakat agar Kaeran sebagai keponakan mereka menggantikan posisi saudara perempuan mereka (Saminem bin Martonadi) yang lebih dahulu meninggal dari Katimun bin Martonadi, sebab dalam kenyataannya mereka secara bersama-sama melawan istri almarhum Katimun bin Martonadi, yaitu Ngadiem alias Tumbu yang menguasai harta terperkara. Selanjutnya, hakim pada tingkat pertama, dalam konsiderans putusannya 
menyatakan bahwa Kaeran selaku anak laki-laki dari almarhumah Saminem binti Martonadi sebagai ahli waris pengganti, dapat disetujui dan dibenarkan, berdasarkan maksud Putusan Mahkamah Agung RI tanggal 14 Agustus 1957 Nomor 143 K/Sip/1956.

Pengadilan Tinggi Agama Medan dengan hakim Drs. Matardi E., SH sebagai Hakim Ketua Majlis, Drs. H. Amran Suadi, SH dan Drs. Ahmad Sagu Harahap, SH sebagai hakim anggota serta Sunaryati, SH sebagai Panitera dalam keputusannya tanggal 11 Februari 1999 mengabulkan gugatan Penggugat/Pembanding untuk sebagian dengan verstek, menetapkan ahli waris dari almarhum Katimun bin Martonadi yang meninggal pada tanggal 14 Desember 1994 seperti yang diputuskan oleh PA Lubuk Pakam dan menetapkan bagian masing-masing sebagai berikut: Ngadiem alias Tumbu memperoleh 6 bagian. Samikun bin Martonadi sebagai saudara laki-laki kandung memperoleh 6 bagian. Samingun bin Martonadi selaku saudara laki-laki kandung memperoleh 6 bagian. Mirah binti Martonadi selaku saudara perempuan kandung memperoleh 3 bagian. Kaeran sebagai waris pengganti dari almarhumah Saminem binti Martonadi memperoleh 3 bagian.

2. Putusan Pengadilan Agama Medan yang diputus pada tanggal 24 Februari 1999 Nomor 367/Pdt.G/1998/PA-Medan, yang duduk perkaranya sebagai berikut:

Almarhum M. Daud Pulungan telah meninggal dunia pada tanggal 1 Agustus 1990 di Medan. Semasa hidupnya almarhum mempunyai seorang istri bernama Habsah yang telah meninggal dunia pada tanggal 13 Nopember 1995 dan mempunyai anak kandung sebanyak 6 (enam) orang, yaitu: M. Yakub Pulungan (anak laki-laki kandung). Zainab Pulungan (anak perempuan kandung), meninggal dunia pada tanggal 30 Mei 1988 dan meninggalkan anak (cucu dari M. Daud Pulungan) sebanyak 6 (enam) orang, masingmasing bernama Nurmala, Zulkifli, Nurlani, Nurlela, Nurlina dan Nurmaida. Asnah Pulungan (anak perempuan kandung). Nafsiah Pulungan (anak perempuan kandung) meninggal dunia pada tanggal 6 Oktober 1992 dengan tidak meninggalkan keturunan. Salbiah Pulungan (anak perempuan kandung). Misran Pulungan (anak laki-laki kandung)

Tuntutan penggugat dalam hal ini M. Ya'kub ke Pengadilan Agama Medan adalah agar dapat diputus perkaranya antara lain menetapkan ahli waris almarhum M. Daud Pulungan. Setelah tahapan pemeriksaan dilakukan, maka oleh majlis hakim yang terdiri dari Drs. Syahron Nasution, SH (Ketua), Drs. M. Taufiq dan Mawardi Lingga masingmasing sebagai hakim anggota, telah dipertimbangkan bahwa ahli waris almarhum $\mathrm{M}$. Daud Pulungan terdiri dari seorang istri, 5 (lima) orang anak dan 6 (enam) orang cucu yang menggantikan kedudukan almarhum Zainab Pulungan yang telah meninggal dunia lebih dahulu dari si pewaris.

Pada tanggal 24 Februari 1999 perkara ini diputus oleh majlis hakim. Amar putusannya antara lain menetapkan bahwa ahli waris M. Daud Pulungan dan Habsah adalah M. Ya'kub Pulungan, Asnah Pulungan, Salbiah Pulungan, Misran Pulungan dan Waris Pengganti dari almarhum Zainab Pulungan yang terdiri dari 6 (enam) orang cucu. 
Dasar hukum yang digunakan oleh hakim dalam pengambilan keputusannya adalah Pasal 185 ayat (1) dan (2) Kompilasi Hukum Islam.

\section{Penetapan Pengadilan Agama Medan Nomor 36/Pdt.P/2005/PA. Medan.}

Penetapan ini dijatuhkan di Medan pada hari Rabu tanggal 24 Agustus 2005 oleh Drs. Habibuddin, SH, MH (Ketua Majlis), Drs. M. Taufik, SH, MH dan Drs. Sohel, SH masingmasing sebagai hakim anggota dan dibantu oleh Sugeng Heriono, SH sebagai Panitera Pengganti. Duduk perkaranya adalah sebagai berikut:

Almarhum Amaluddin Siregar bersama istrinya Sjajamani dan tiga orang anak mereka, yakni Ir. Mawardi, M.Si, Dewi Juliana dan Erma Surya telah meninggal dunia pada tanggal 26 Desember 2004, karena terkena gempa bumi dan gelombang Tsunami di Nanggroe Aceh Darussalam. Almarhum Amaluddin Siregar mempunyai 1 (satu) orang saudara kandung laki-laki bernama Sorimatua Siregar yang telah meninggal dunia pada tahun 1995, meninggal lebih dahulu dari almarhum Amaluddin Siregar. Almarhum Sorimatua mempunyai 3 (tiga) orang anak kandung, yakni: M. Yusuf Shirot Siregar, sebagai anak laki-laki, telah meninggal dunia pada tanggal 16 Juli 2005 dan meninggalkan 3 (tiga) orang anak, yakni Herry M. Siregar, Irfan Abdillah Siregar dan Fahru Rozy Siregar. Hasnah Mawarni (anak perempuan), dan Hj. Rosita (anak perempuan)

Yang bertindak sebagai pemohon dalam hal ini adalah Irfan Abdillah, Nurhayati (istri alm. M. Yusuf Shirot Siregar), Fahru Razu Siregar, Hasnah Mawarni dan Hj. Rosita. Mereka memohon kepada majlis hakim untuk menetapkan ahli waris almarhum Amaluddin Siregar.

Majlis hakim mengabulkan permohonan pemohon. Dalam keputusannya, majlis menetapkan bahwa karena Sorimatua Siregar yang meninggal pada tahun 1995 sebagai satu-satunya saudara kandung dari almarhum Amaluddin Siregar maka M. Yusuf Shirot Siregar, Hasnah Mawarni dan Hj. Rosita sebagai ahli waris pengganti dari almarhum Sorimatua Siregar yang berhak atas harta peninggalan almarhum Amaluddin Siregar. Keputusan ini mereka ambil berdasarkan ketentuan pasal 185 ayat (1) Kompilasi Hukum Islam.

4. Penetapan PA Medan Nomor 47/Pdt.P/2005/PA. Medan, yang penetapannya dijatuhkan di Medan pada tanggal 18 Oktober 2005. Duduk perkaranya adalah sebagai berikut:

Almarhumah Wan Nazariah meninggal dunia pada tanggal 24 Nopember 1998 karena sakit tua dan dalam keadaan beragama Islam. Almarhumah Wan Nazariah semasa hidupnya tidak pernah menikah. Almarhumah hanya mempunyai 2 (dua) orang saudara kandung bernama: Wan Masyatah (perempuan) dan telah meninggal dunia pada tahun 1994, dan H. Dt. Bahaoeddin (laki-laki) yang telah meninggal dunia pada tanggal $26 \mathrm{Mei}$ 1978. 
Almarhumah Wan Masyatah di saat meninggal dunia meninggalkan 10 (sepuluh) orang anak, sedangkan almarhum H. Dt. Bahaoeddin meninggalkan 6 (enam) orang anak yang masih hidup dan satu orang anak yang telah meninggal dunia tanpa menikah.

Para pemohon yang berjumlah 16 (enam belas) orang tersebut memohon kepada majlis hakim supaya ditetapkan ahli waris untuk mengurus harta peninggalan almarhumah Wan Nazariah.

Majlis Hakim Pengadilan Agama Medan yang terdiri dari Drs. Habibuddin $\mathrm{SH}, \mathrm{MH}$ (Hakim Ketua), Drs. M. Taufik, SH, MH (Hakim Anggota), Drs. Sohel, SH (Hakim Anggota) dan Sugeng Heriono, SH (Panitera Pengganti) mengabulkan permohonan para pemohon, sekaligus menetapkan ahli waris yang mustahaq dari almarhumah Wan Nazariah yang telah meninggal dunia pada tanggal 24 Nopember 1998. Mereka adalah $\mathrm{Hj}$. Wan Mourida berjumlah 10 (sepuluh) orang, yakni anak laki-laki dan perempuan dari saudara kandung perempuan dari pewaris dan Elvina Bahaoeddin berjumlah 6 (enam) orang, yakni anak laki-laki dan perempuan dari saudara kandung laki-laki Wan Nazariah.

Dasar hukum yang dipergunakan dalam penetapan tersebut adalah ketentuan Kompilasi Hukum Islam pasal 185 ayat (1), karena dari isinya dipahami bahwa anak saudara perempuan dan laki-laki dapat menempati kedudukan orang tuanya sebagai ahli waris pengganti.

\section{Pembahasan}

Setelah menelaah putusan pada masing-masing periode, perlu dijelaskan bahwa pada periode pertama, tahun 1977 sampai dengan tahun 1984, majlis hakim yang memutus perkara ahli waris dan anak dari ahli waris yang lebih dahulu meninggal dunia dari si pewaris diambil dua majlis dari PTA Medan, masing-masing majlis terdiri dari satu orang ketua dan dua orang anggota yang secara ril berjumlah empat orang hakim. Tiga orang di antaranya terdiri dari ulama dan sudah meninggal dunia, kesemuanya adalah alumni pesantren dan satu orang dari mereka bergelar magister yang diperoleh dari Universitas al-Azhar, sedangkan sisanya adalah hakim PNS telah pensiun dan berdomisili di Medan. ${ }^{13}$

Pada periode ini majlis hakim PTA Medan memberikan putusan yang bervariasi terhadap status cucu pewaris dari anaknya yang lebih dahulu meninggal dunia. Majlis hakim kasus pertama di atas memutuskan bahwa cucu dari anak yang lebih dahulu meninggal dari pewaris sebagai ahli waris ashabah, sedangkan majlis hakim sidang kasus kedua memutuskan bahwa cucu tidak termasuk sebagai ahli waris. Indikator dari kesimpulan kasus kedua adalah bahwa hakim PTA dalam keputusannya tidak membantah dan mengoreksi status cucu (Saniyah dan Abd. Rahman) pewaris (Siti Nalaboh) dari anaknya

${ }^{13}$ Informasi diperoleh melalui wawancara dengan Drs. Abdur Rahman Har, SH, Hakim Tinggi PTA Medan pada tanggal 7 Februari 2005 di PTA Medan. 
perempuan (Ruhima) yang lebih dahulu meninggal dunia dari pewaris yang oleh PA Gunung Sitoli ditetapkan tidak termasuk sebagai ahli waris yang mustahaq memperoleh warisan. Ini berarti bahwa hakim PTA Medan secara implisit setuju dengan status cucu tidak dihitung sebagai ahli waris.

Keputusan hakim PTA Medan untuk dua kasus terdahulu berbeda satu sama lain, padahal masalahnya sama-sama penetapan status cucu. Pada kasus pertama cucu ditetapkan oleh hakim sebagai ahli waris ashabah yang berhak memperoleh seluruh sisa harta, sedangkan pada kasus kedua status cucu ditetapkan tidak termasuk dalam klasifikasi ahli waris. Keputusan ini kelihatannya sangat dipengaruhi oleh ketentuan Hukum Warisan Islam Klasik yang menganggap status cucu (ibn al-ibn dan bint al-ibn) dari anak laki-laki sebagai ashabah berbeda dengan status cucu dari anak perempuan yang sama sekali tidak dihitung sebagai ahli waris. ${ }^{14}$ Temuan yang diperoleh menunjukkan adanya perbedaan status cucu laki-laki dengan cucu perempuan dalam hal ini, namun sikap hakim dalam putusannya relatif sejalan dengan Hukum Warisan Islam Klasik menurut jumhur ulama, walaupun terbuka peluang bagi mereka untuk mengutip pendapat lain dari kitab fiqih klasik yang mungkin menggiring mereka untuk memberikan putusan yang berbeda dengan putusan-putusan sebelumnya.

Untuk periode pertama tahun 1985 sampai dengan pertengahan tahun 1991 diambil satu majlis dari PTA Medan. Majlis ini diisi oleh hakim karir. Mereka pada umumnya telah bertugas di atas sepuluh tahun dan memiliki latar belakang S1 Syari'ah. Mereka memeriksa kasus yang berada pada masa transisi pemberlakuan Kompilasi Hukum Islam, yang didaftarkan untuk banding di PTA Medan pada awal tahun 1991. Untuk kasus ini keputusan PTA Medan relatif berbeda dengan keputusan sebelumnya dan dengan keputusan PA asal perkara. Faktanya menunjukkan bahwa hakim PA Tebing Tinggi pada tahun 1990 memutuskan penetapan ahli waris dari pewaris (almarhum Kudin) dengan tidak mengikutsertakan cucu pewaris (Lukman dan Masnun) dari anak laki-laki yang telah lebih dahulu meninggal dunia (M. Saib bin Kudin) dari pewaris. Keputusan tersebut membuktikan bahwa hakim PA Tebing Tinggi menganggap kedua orang cucu di atas tidak termasuk ahli waris. Namun hakim PTA Medan dalam keputusan banding membatalkan keputusan PA Tebing Tinggi dan menyatakan bahwa kedua orang cucu pewaris menurut ketentuan Kompilasi Hukum Islam berkedudukan sebagai ahli waris pengganti.

Jadi, dari dua keputusan ini dapat dilihat secara jelas perbedaan sikap hakim dalam memutuskan perkara yang sama. Di satu sisi hakim PA Tebing Tinggi pada tahun 1990 tidak menganggap kedua orang cucu terdahulu sebagai ahli waris, tetapi hakim PTA Medan dalam putusannya berpendapat sebaliknya. Walaupun perkara tersebut akhirnya tidak dilanjutkan pemeriksaannya karena alasan persyaratan formil belum terpenuhi,

${ }^{14}$ Idris Djakfar dan Taufik Yahya, Kompilasi Hukum Kewarisan Islam (Jakarta: Pustaka Jaya, 1995), h. 57-58. 
namun sikap yang ditunjukkan hakim PTA Medan mengindikasikan adanya keinginan yang kuat untuk merubah penerapan hukum terhadap cucu tidak seperti yang sudah terjadi selama ini.

Mencermati putusan pada periode pertama jelas kelihatan adanya keinginan yang kuat dari sebagian masyarakat untuk mengikut sertakan keturunan ahli waris yang lebih dahulu meninggal dari pewaris menjadi waris yang berhak memperoleh warisan. Hal ini dibuktikan dengan langkah mereka memasukkan keturunan yang demikian dalam surat permohonan penetapan ahli waris ke pengadilan tingkat banding walaupun pada akhirnya palu hakim belum berpihak pada tuntutan yang diajukan. Setidaknya, langkah yang diambil oleh masyarakat (pihak keluarga) menjadi bukti adanya interaksi antara pengadilan dengan masyarakat yang menuntut perlakuan yang lebih baik dari hukum terhadap orang yang menjadi pokok bahasan.

Untuk periode kedua atau setelah berlakunya secara efektif Kompilasi Hukum Islam, yakni mulai dari akhir Juli 1991 sampai dengan tahun 2005 diambil empat majlis, satu majlis dari PTA dan tiga majlis dari PA Medan, yang secara ril berjumlah sembilan orang hakim. Hakim PTA yang memeriksa perkara ini rata-rata berlatar belakang S1 Syari'ah dan S1 Hukum Umum dan telah bertugas di atas dua puluh tahun, sedangkan hakim PA juga berlatar belakang S1 Syari'ah dan S1 Hukum Umum dan telah bertugas lebih sepuluh tahun. ${ }^{15}$ Pada periode ini sikap hakim dalam penetapan ahli waris pengganti sangat dipengaruhi oleh isi pasal-pasal yang ada di dalam KHI. Hal ini dapat dilihat dari putusan PTA Medan tanggal 11 Februari 1999 (kasus nomor 1) yang menetapkan keturunan dari anak perempuan yang lebih dahulu meninggal dari pewaris sebagai ahli waris pengganti. Keturunan ini pada masa sebelumnya sesuai ketentuan Hukum Warisan Islam Klasik tidak termasuk sebagai ahli waris, sehingga mereka oleh generasi belakangan dianggap telah diperlakukan hukum warisan Islam secara diskriminatif. Dengan kedatangan KHI maka sifat diskriminasi tersebut dapat dihilangkan.

Sama halnya dengan langkah yang diambil hakim dalam memutus kasus pertama, sikap mereka untuk kasus kedua memberlakukan ketentuan ahli waris pengganti dan menetapkan cucu dari anak perempuan yang lebih dahulu meninggal dunia dari pewaris sebagai ahli waris pengganti. Hal ini terlihat secara jelas di dalam putusannya seperti telah dikemukakan terdahulu. Dengan demikian, mereka yang semula dalam fiqih klasik tidak termasuk ahli waris, maka melalui ketentuan yang diatur oleh pasal $185 \mathrm{KHI}$ dinyatakan sebagai ahli waris menggantikan posisi orangtuanya dan selanjutnya berhak memperoleh bagian dari warisan.

Tidak berbeda dengan sikap mereka sebelumnya, hakim PA Medan dalam memutus kasus yang sama di tahun 2005 menetapkan M. Yusuf Shirot Siregar, Hasnah Mawarni dan Hj. Rosita sebagai ahli waris pengganti dari almarhum Sorimatua Siregar yang

${ }^{15}$ Informasi ini diperoleh dari file data kepegawaian hakim PTA Medan. 
berhak atas harta peninggalan almarhum Amaluddin Siregar. Demikian juga pada kasus 4 dimana Hj. Wan Mourida dan Elvina sebagai ahli waris untuk menggantikan posisi orangtua mereka. Dasar hukum yang digunakan untuk penetapan tersebut juga diilhami oleh isi pasal $185 \mathrm{KHI}$. Keempat kasus di atas menjadi fakta historis bahwa hakim Peradilan Agama pada periode kedua memberikan putusan yang sama dalam penetapan ahli waris pengganti.

Jadi, keputusan terdahulu menggambarkan terjadinya pergeseran sikap hakim dari masa sebelum tahun 1991 dengan masa setelah keluarnya KHI dalam memutus perkara mengenai status keturunan dari ahli waris yang lebih dahulu meninggal dari pewaris. Faktor yang mempengaruhi sikap hakim pada periode pertama tahun 1977 sampai dengan tahun 1984 diantaranya: Pertama adanya ketentuan sejumlah kitab fiqih klasik yang dapat dijadikan rujukan bagi penetapan status keturunan ahli waris yang lebih dahulu meninggal dunia dari pewaris memberi peluang yang lebih besar untuk lahirnya putusan yang tidak seragam. Namun dari kasus yang ada diketahui bahwa putusan yang diberikan konsisten dengan pendapat jumhur ulama. Kedua, belum adanya aparatur yang memadai. Pada periode ini dapat dilihat bahwa sebagian besar hakim yang memutus perkara ketika itu adalah hakim honorer yang diangkat berdasarkan SK Direktur Badan Peradilan Agama Departemen Agama RI. Ketiga, kedudukan lembaga peradilan agama pada periode ini tidak memiliki wewenang penuh untuk menyelesaikan masalah kewarisan, karena tugasnya terbatas pada penetapan ahli waris dan penentuan bagian masing-masing, sedangkan melaksanakan pembagian warisan secara langsung dilakukan oleh Pengadilan Negeri. Dengan demikian, putusan-putusannya tentang kewarisan dipandang tidak kuat karena tidak sampai pada titik akhir penyelesaian permasalahan.

Sikap hakim pada periode pertama tahun 1985 sampai dengan pertengahan tahun 1991 dipengaruhi oleh hiruk pikuk perundang-undangan baru. Di antaranya lahirnya Undang-undang Nomor 7 Tahun 1989 tentang Peradilan Agama yang menghapus perlunya pengukuhan Pengadilan Umum terhadap setiap keputusan Pengadilan Agama dan memberi peluang bagi hakim Pengadilan Agama untuk memutus dan melakukan eksekusi terhadap masalah pembagian warisan disamping wewenang menetapkan ahli waris yang sudah diperoleh sebelumnya. Undang-undang yang sama menutup kesempatan untuk mengangkat hakim honorer karena di dalam peraturan tersebut ditegaskan secara ekplisit bahwa hakim Peradilan Agama haruslah PNS. ${ }^{16}$

Pada periode kedua atau setelah berlakunya secara efektif Kompilasi Hukum Islam yang merupakan kitab hukum formal yang unifikatif dan kodifikatif, hakim tidak mempunyai hak absolut lagi untuk menentukan keinginannya dalam memilih hukum yang akan diterapkan, mereka telah dibimbing ke arah keseragaman dalam memberikan putusan. Temuan di lapangan memang mendukung statement terdahulu.

${ }^{16}$ Pagar, Himpunan Peraturan Perundang-Undangan Peradilan Agama di Indonesia (Medan: IAIN Press, 1995), h. 245. 
Tabel 1. Dasar Putusan Pengadilan Agama di Medan dalam memutus Perkara Ahli Waris Pengganti ${ }^{17}$

$$
\mathrm{n}=8 \text { orang }
$$

\begin{tabular}{|l|l|c|r|}
\hline No & \multicolumn{1}{|c|}{ Uraian } & Frekuensi & Persentase \\
\hline 1. & Berdasarkan Pasal 185 KHI & 8 & $100 \%$ \\
\hline 2. & Berdasarkan ketentuan selain Pasal 185 KHI & 0 & $0 \%$ \\
\hline & J u m l a h & 8 & $100 \%$ \\
\hline
\end{tabular}

Tabel 1 di atas menggambarkan bahwa yang menjadi dasar putusan pengadilan dalam penetapan ahli waris menurut semua hakim yang diwawancarai adalah pasal 185 Kompilasi Hukum Islam. Alasan yang mereka kemukakan dalam menerapkan pasal tersebut dapat dilihat pada Tabel 2 di bawah ini.

Tabel 2. Alasan Pengadilan Agama di Medan Menggunakan Pasal 185 KHI

$\mathrm{n}=8$ orang

\begin{tabular}{|l|l|c|c|}
\hline No & \multicolumn{1}{|c|}{ Uraian } & Frekuensi & Persentase \\
\hline 1. & Memenuhi rasa keadilan & 5 & $62,5 \%$ \\
\hline 2. & Untuk kepastian hukum & 2 & $25,0 \%$ \\
\hline 3. & $\begin{array}{l}\text { Tidak bertentangan dengan Hukum } \\
\text { Kewarisan Islam }\end{array}$ & - & - \\
\hline 4. & $\begin{array}{l}\text { Ada Instruksi Presiden RI dan Keputusan } \\
\text { Menag RI }\end{array}$ & 1 & $12,5 \%$ \\
\hline & J u m l a h & 8 & $100 \%$ \\
\hline
\end{tabular}

Tabel 2 di atas menggambarkan bahwa 5 orang (62,5\%) hakim yang diwawancarai yang bertugas di Peradilan Agama Medan menjawab bahwa pasal $185 \mathrm{KHI}$ diterapkan dalam penetapan ahli waris pengganti, karena lebih memenuhi rasa keadilan, 2 orang hakim (25\%) mengatakan bahwa pasal dimaksud dijadikan dasar penetapan ahli waris pengganti untuk terciptanya kepastian hukum dan hanya 1 orang $(12,5 \%)$ yang mengatakan menerapkan pasal yang sama karena adanya Instruksi Presiden RI dan Keputusan Menteri Agama. Dengan demikian, dapat disimpulkan bahwa sebagian besar hakim berpendapat bahwa apa yang diamanatkan oleh isi pasal $185 \mathrm{KHI}$ itu lebih sesuai dengan kondisi masa kini dari pada menerapkan ketentuan Hukum Warisan Islam Klasik.

Memang harus diakui bahwa kehadiran KHI bukanlah satu-satunya faktor yang

${ }^{17}$ Data diperoleh dan diolah dari hasil wawancara dengan 5 orang hakim PTA dan 3 orang hakim PA Medan pada tanggal 6 dan 7 Februari 2006 untuk mendapatkan data pendukung bagi keterbatasan informasi lebih lanjut dari hakim yang memutus perkara kasus yang diteliti karena sebagian telah meninggal, pensiun atau mutasi. 
menyebabkan terjadinya pergeseran sikap hakim dalam penetapan keturunan dari ahli waris yang lebih dahulu meninggal dunia dari pewaris sebagai ahli waris pengganti. Faktor lain adalah globalisasi dan modernisasi yang berakibat pada terjadinya perubahan budaya dan selanjutnya mempengaruhi pemikiran masyarakat dan menimbulkan reaksi terhadap perlakuan lingkungan dan keputusan hakim kepada orang-orang yang menjadi perbincangan. Konsekuensinya adalah bahwa sebagian masyarakat dan pihak terkait tidak segan dan semakin berani mempertanyakan posisinya di depan hukum. Faktor ini adalah faktor yang telah direkam oleh pengambil keputusan dalam masa persiapan pembentukan Kompilasi Hukum Islam.

Selain itu, karena zaman sekarang adalah zaman transparansi maka praktisi hukum yang melakonkan role (kedudukan) ${ }^{18}$ sebagai hakim dituntut untuk ekstra hati-hati di dalam mengambil keputusan, dalam arti keputusannya harus sesuai dengan ketentuan yang ada, sehingga keputusan yang diambil dapat memenuhi rasa keadilan masyarakat sebagai pencari keadilan.

Akhirnya, fakta yang diperoleh menunjukkan bahwa keputusan hakim telah beranjak dari satu posisi hukum ke posisi hukum yang lain tanpa disadari bahwa hukum dan keputusan hakim belakangan telah keluar dari hukum Islam Klasik, ${ }^{19}$ dalam arti hukum dan keputusan yang diambil adalah hukum Islam baru yang lebih sesuai dengan konteks Indonesia.

\section{Kesimpulan dan Saran}

Pada masa sebelum tahun 1991 tidak dikenal istilah ahli waris pengganti, namun kasusnya sudah ada ketika itu. Ahli waris yang demikian pada masa itu diperlakukan berbeda oleh hukum (hakim), khususnya mengenai masalah cucu. Keturunan dari anak perempuan yang lebih dahulu meninggal dunia dari pewaris tidak termasuk ahli waris bagi pewaris, akan tetapi untuk keturunan dari anak laki-laki yang lebih dahulu meninggal dunia dari pewaris, Peradilan Agama memutuskan sebaliknya. Namun setelah keluarnya Kompilasi Hukum Islam terjadi pergeseran sikap mereka merespons status keturunan dari ahli waris yang lebih dahulu meninggal dunia dari pewaris ke arah yang semakin seragam dalam memberikan keputusan. Pergeseran sikap ini sejalan dengan kehadiran KHI, posisi para hakim yang secara administratif sebagai aparatur yang diangkat dan diberhentikan oleh pemerintah dan perubahan sosial ke masyarakat yang lebih mengedepankan equalitas.

${ }^{18}$ Malcolm Waters dan Rodney Crook, Sociology: Principles of Sociological Analysis for Australians (Melbourne: Longman Cheshire, 1990), h. 33.

${ }^{19}$ Mohamad Atho Mudzhar, Islam and Islamic Law in Indonesia: A Socio Historical Approach (Jakarta: Office of Religious Research and Development and Training, Ministry of Religious Affairs Republic of Indonesia, 2003), h. 101. 


\section{Pustaka Acuan}

Babbie, Earl. The Practice of Social Research. Belmot, California: Wadsworth Publishing Company, 1989.

Coulson, N.J., Succession in the Muslim Family. Cambridge: The University Press, 1971.

Djakfar, Idris H. dan Taufik Yahya. Kompilasi Hukum Kewarisan Islam. Jakarta: Pustaka Jaya, 1995.

Departemen Agama RI. Kompilasi Hukum Islam di Indonesia. Jakarta: Departemen Agama RI, Ditbinperta, 1997/1988.

Hadi, Sutrisno. Metodologi Research. Jilid I. Yogyakarta: Yayasan Penerbitan Fakultas Psikologi UGM, 1981.

Humphreys, R. Stephen. Islamic History: A Framework for Inquiry. USA: Bibliotheca Islamica, Minneapolis, 1988.

Ibn $\underline{\text { Hazm, }}$ Alî ibn Ahmad. al-Muhalla. Kairo: Idarah at-Tiba'ah al-Muniriyah, 1347 H.

Keputusan PTA Medan No. 04/1977, tanggal 4 Mei 1977.

Keputusan PTA Medan No. 04/1979, tanggal 31 Januari 1979.

Mudzhar, Mohamad Atho. Islam and Islamic Law in Indonesia: A Socio Historical Approach. Jakarta: Office of Religious Research and Development and Training, Ministry of Religious Affairs Republic of Indonesia, 2003.

Pagar. Himpunan Peraturan Perundang-Undangan Peradilan Agama di Indonesia. Medan: IAIN Press, 1995.

Pagar. "Sisi Keadilan Ahli Waris Pengganti Dalam Pembaharuan Hukum Islam Indonesia: Suatu Kajian Terhadap Kompilasi Hukum Islam Indonesia", Disertasi pada Program Doktor IAIN Syarif Hidayatullah. Jakarta: IAIN Syarif Hidayatullah, 2001.

Penetapan PA Medan No. 47/Pdt.P/2005/PA.Mdn, tanggal 18 Oktober 2005.

Penetapan Pengadilan Agama Medan No. 36/Pdt.P/2005/PA.Mdn, tanggal 24 Agustus 2005.

Putusan Pengadilan Agama No. 367/Pdt.G/1998/PA-Mdn, tanggal 24 Februari 1999.

Putusan PTA Medan No. 05/PTS/1991/1992/PTA Mdn, tanggal 29 Juni 1992.

Al-Râkhilî, Wahbah. al-Fiqih al-Islâm wa Adillatuh. Juz VIII, cet. 3. Damsyik: Dâr al-Fikr, 1989.

Rakhmad, Jalaluddin. Psikologi Komunikasi. Bandung: Remaja Rosdakarya, 1986.

Syarifuddin, Amir. Hukum Kewarisan Islam. Jakarta: Prenada Media, 2004.

Waters, Malcolm dan Rodney Crook. Sociology: Principles of Sociological Analysis for Australians. Melbourne: Longman Cheshire, 1990. 